\title{
"I was crying, I did not come back with anything": Women's Experiences of Deportation from Europe to Nigeria
}

\author{
Emma Ratia $^{\mathrm{a}}$ and Catrien Notermans ${ }^{\mathrm{b}}$ \\ a) Radboud University Nijmegen, The Netherlands \\ emma@ratia.org \\ b) Radboud University Nijmegen, The Netherlands \\ c.notermans@maw.ru.nl
}

\begin{abstract}
The aim of this article is to study the impact of deportation on women's lives, via the narrated experiences of Nigerian women deported from the European Union. It focuses on women's stories about the period prior to their travel to Europe and their motivations for doing so; on stories about the journey and their experiences as migrants; and finally on stories about their deportation and their life after returning home to Nigeria. By taking this three-step approach and by focusing on deportees' experiences, the authors want to contribute to an emic understanding of deportation in which gender and kinship play a crucial part. The obligation to migrate is a social as well as an economic duty for women in the Nigerian context. Whereas anthropological studies have so far focused on deportees' feelings of non-belonging, this article shows that women's experiences of deportation are highly connected to family belonging.
\end{abstract}

\section{Keywords}

migration, deportation, gender, Nigeria, cultural anthropology

\section{Résumé}

Cet article cherche à étudier l'impact de l'expulsion sur la vie des femmes nigérianes à travers des expériences relatées par des Nigérianes qui ont été expulsées de l'Union européenne. L'article vise à souligner les histoires de ces femmes pendant trois étapes différentes. En premier lieu, il décrit la période qui précède leur départ vers l'Europe de même que leurs motivations pour partir. Ensuite, leurs histoires du trajet et leurs expériences comme immigrantes sont exposées. Finalement, l'article dépeint les histoires des expulsions et des vies de ces femmes une fois rentrées au Nigeria. En se concentrant sur les expériences des expulsées, les auteurs cherchent à contribuer à une compréhension émique de l'expulsion dans laquelle genre et parenté jouent un rôle important. Dans un contexte nigérian, les femmes assument l'obligation de migrer comme un devoir social et économique. Alors que l'anthropologie s'est surtout intéressée aux sentiments de 
non-appartenance des expulsés, cet article démontre que les expériences d'expulsion de ces femmes sont fortement liées à un sentiment d'appartenance familiale.

Mots-clés

migration, expulsion, genre, Nigeria, anthropologie culturelle

In 2003, Pauline found herself on a plane from Rome to Lagos as one of some 100 Nigerians being deported from Italy to Nigeria. When looking back at this experience, she says: "I was crying, this is how I ended, I did not come back with anything. (...) I was left with this shirt and these jeans and nothing else." Pauline slaps her thighs: "Just trousers and a shirt, nothing else." For Pauline, this was the end of a journey that had taken her through the Sahara desert to Morocco, almost drowned her in the Mediterranean and eventually led to her being sold to a madam $^{1}$ for 5,00o US dollars and being forced into sex work ${ }^{2}$ in Italy. Pauline was just one of many Nigerians deported from the European Union in 2003. Pauline's story (which will be developed further on) illustrates the hardships that the recent "deportation turn" (Gibney, 2008) in immigration policies of the West European countries of the European Union entails for individual deportees. In this article, we study the implications of deportation for women's lives by focusing on the narrated experiences of Nigerian women deported from the European Union.

Since the 1990s, the return of refugees and unwanted immigrants to their countries of origin has played an increasingly significant role in immigration debates and policies in various Western countries. Researchers soon noted that return can have far-reaching negative consequences for the well-being of returnees (Koser and Black, 1999). In recent years, forced return, i.e. deportation, has attracted the attention of a growing number of scholars. This body of work focuses on the conditions of undocumented migrants and their 'deportability' (De Genova, 2002; Khosravi, 2009; Wicker, 2010), the consequences of deportation for notions of (nation) state and citizenship (Anderson, Gibney and Paoletti, 2011) and the problems deportation poses for human rights and

1) "Madam" is the common term used in Nigeria for women who organize the migration of other women to Europe for sex work. The term is also used for women who run the day-to-day operation of sex work in Europe.

2) The informants always spoke about "prostitution." In academic discourse, the term "sex work" better reflects our feminist concerns about turning women into victims, which is why we use this term whenever possible. 
immigration policy (Andrijasevic, 2009). Most of this literature emphasizes the legal and social ramifications of deportation for Western countries whereas relatively few studies focus on the consequences for the deportees themselves (c.f. Drotbohm, 2011; Zilberg, 2004; Yngvesson and Coutin, 2006; Peutz, 2006; Miller, 2011; Willen, 2007). In line with these studies we focus on the perspective of the deportees themselves, as it is through this emic perspective that we may understand their deportation trajectories and how deportation ultimately affects them.

In the emerging field of deportation studies, gender has so far been relatively neglected, although Peutz (2006: 223-224) suggests that the disruptions of social life brought about by deportation are all gendered. Many studies of deportation have shown a strong overrepresentation of men among the deportees without further analyzing the underlying reasons for this gender bias (Peutz, 2006; Zilberg, 2004; Hagan et al., 2008). The case of Nigerian women is self-evidently gendered. Women from Edo State in the South-South region of Nigeria have received a good deal of attention in the European and Nigerian media as a result of their migration to Europe to engage in sex work. In the last 15 years, these women have been deported en masse, especially from Italy (Carling, 2006; De Haas, 2008). In this context, people associate migration more with women than with men. In line with studies like Donato's (2006) and Mahler's (2006), we will argue here that gender is crucial to an understanding of Nigerian women's migration and their experiences of deportation, as it influences the decision to travel, the nature of their migration trajectories, and the subsequent experiences of deportation.

Despite a growing body of work dealing with deportation, its social ramifications have been understudied (Peutz and De Genova, 2010: 5), but have recently received more consideration (c.f. Drotbohm, 2011). Studies of deportees point to a radical kind of non-belonging and the impossibility of belonging after deportation (Peutz, 2006; Yngvesson and Coutin, 2006; Zilberg, 2004), as well as to the presence of a nation state in the lives of the deportees (Boehm, 2009; Talavera, Nuñez-Mchiri, and Heyman, 2010). All in all, such studies tend to adopt an individualistic perspective in demonstrating the detachment of deportees from their social framework in the country they have been deported to. We believe more attention should be given to the effects of deportation on social relationships, particularly in West Africa, where social relationships play a crucial role in people's lives; West Africans experience themselves not as having relationships but as being relationships (Piot, 1999) and consciously construct their families across (inter)national and continental boundaries 
(Drotbohm, 2009; Fleischer, 2007; Hagan et al., 2008). A disruption of social, and in particular kin relationships, such as that caused by deportation, is then bound to affect peoples' health and sense of being in fundamental ways.

As deportation has been insufficiently studied from the perspective of the deportees and as little attention has been paid to gender and social relationships, our central research question is: how is deportation experienced by women who are deported from the European Union to Nigeria and how do gender and kinship matter in these experiences? To answer this research question, Ratia carried out two months of ethnographic fieldwork in the spring of 2010, in the capital city of Edo State, Benin City. This location was chosen for fieldwork because many women migrants originate from there and also return there after their deportation. During fieldwork, narratives were collected from 17 (80\% of the sample) deportee women, deported from different European countries (Netherlands, Spain and Italy) between 1995 and 2010. For the sake of gender comparison, four $(20 \%$ of the sample) deportee men were also included in the study. Seven of the women were contacted through the help of NGOs in Benin City, and the others were found by means of "snowball sampling" (Bernard, 2002). Though the majority of informants said they were not open about their deportation, most informants were contacted through people who knew them and who knew they had been deported.

Women's narratives were collected through informal talks on different occasions, using participant observation (Bernard, 2002), as this was the most appropriate way to overcome the problems of silence, secrets, and shame associated with deportation. It turned out to be impossible to conduct formal interviews on such a difficult topic, which is why much of the data was gathered while the informants went about their daily activities, such as preparing food or socializing with friends. Activities where eye contact is not necessary (walking to the market, preparing food, watching television) were most productive for bringing up painful issues such as family relationships and sex work. In the company of others, such as in a bar, it was easier to discuss life prior to and during traveling, as this was a topic everyone had something to say about. Obviously, this use of participant observation greatly affected the type of data that could be collected. The narrated information was saved and remembered via head notes and scratch notes (key words, phrases, and short citations) which soon after the event were developed into expanded stories (Emerson et al., 1995). The stories containing quotes presented in this article therefore have to be seen as truthful reconstructions rather than verbatim transcriptions of recorded interviews. In addition to the fieldwork, Ratia conducted literature research, analyzed the available quantitative data, and interviewed represen- 
tatives of the local government and Non-Governmental Organizations (NGOs) to understand the context of women's migration and deportation stories.

In this article, the terms "deportee" and "informant" always refer to women deportees, except when otherwise stated. The men's narratives are not so much a subject of study as a point of reference against which to check the findings regarding women. Therefore, most material discusses women's situations.

To understand the deportation experience, women were asked about the period prior to their travel to Europe and their motivations for doing so; subsequently they were asked about the journey and their experiences as migrants; and finally they were invited to speak of their deportation and their life after deportation. This article will follow the same structure. The names of the informants have been changed to first names that are common in the studied region to protect their privacy.

\section{"We really like to travel, especially the women": Women's Migration from Edo State to Europe}

The gender aspect of migration cannot be denied when considering people's interpretation of migration. 'Travel' is the emic term used in Benin City for more or less permanent movement abroad; it is never used for tourism or going out of the country on holiday. It is not exclusive to women, as men also travel, but it is often associated with women, and especially with women's migration for sex work in Europe. There is a marked preference within families for sending daughters to Europe instead of sons because daughters are considered more reliable and loyal to the family and will, therefore, be more willing to support their relatives financially (Van Dijk, 2001). Studies of (return) migration in West Africa point to intimate connections between kinship networks, decisions about migration, and economic and social investments (Tiemoko, 2004; Black and King, 2004) but tend to ignore women's motivations to migrate .

The family preference for the migration of daughters was poignantly illustrated when an NGO representative asked Rachel, one of the informants, why she did not get married in Italy in the 8 years she spent there. "I'm there to make money," Rachel said and laughed: "I was thinking how to make everything ok with my parents." Her parents' future instead of her own appeared to be her primary concern. Some local social workers and NGOs even speak of a tendency among families to sacrifice one daughter, knowingly sending her to become a sex worker in Europe, for the benefit of the rest of the family. It was not possible to investigate whether this indeed had been the case for the 
informants. Based on informal talks with Benin City inhabitants on various occasions, it seems that in the first half of the 1990s, it was not widely known that going to Europe might equate to sex work. Since then, Benin City has been a particular target for various campaigns focusing on the dangers of human trafficking and sex work in Europe, resulting in a more general awareness of these dangers.

The social significance of travel becomes evident during a short stroll on the dusty streets of Benin City centre. The yellow Western Union signs are ubiquitous, bearing witness to the significant role remittances from abroad play in the lives of many inhabitants. Benin City had one of the first Western Union branches outside the capital Lagos, making it possible for the women who traveled to Europe en masse in the 1990s to send money back. Along the main roads, one can hardly miss the signs advertising "study abroad," "learn foreign languages here," or "quick passports here." An "Ebo," a white person in the local language, Bini, is greeted by passers-by in Italian, as Italy is a popular travel destination among Nigerians heading for Europe. Routine conversations with people often conclude with locals asking the Ebos to take them or their children with them to Europe because "everything is better up there."

Signifying 'movement abroad,' the emic term "travel" resembles what we, together with other social scientists, would call 'international migration.' In some ways, however, the local notion of 'travel' differs from the academic notion of migration. Firstly, travel is often associated particularly with women's migration, which points to the relevance of the gender dimension of migration and deportation (Brettell, 2003; Donato et al., 2006; Mahler and Pessar, 2006; Pedraza, 1991). Secondly, the deportees talked about their travel using expressions such as "I traveled in 1999," failing to mention their actual destination. Questions about the destination produced a mild irritation among the informants, as they did not consider their destination to have been all that relevant. When talking about returning to Europe, which all the informants hoped to do, it did not matter where they went back to, as long as "I'm not stuck here," as Jane, a 23-year-old deportee woman said. This emphasis on the movement itself echoes the anthropological body of work dealing with mobility in subSaharan Africa. De Bruijn, Van Dijk and Foeken (2001: 1-2) argue that mobility is "fundamental to any understanding of African social life" and encompasses much more than mere movement from one place to another. Mobility, then, can better be seen as a continual movement that characterizes people's way of life.

It is also crucial to understand that the mobility of travel is not merely about horizontal (geographical) mobility but also about vertical (social upward) 
mobility. When Jane and other informants speak about being "stuck here," they do not simply mean the geographical space they are confined to but also the lack of social mobility, which travel was supposed to bring about. Life goes on and leads to better circumstances as long as the movement goes on. This link between geographical and social mobility is illustrated in the attitudes towards deported and voluntarily returned women, the latter usually returning with assets. Whereas the former are often stigmatized because they have failed abroad and are assumed to have been sex workers, the latter are respected by many, even if their money originates from sex work. So, geographical mobility is supposed to result in social mobility and increasing wealth, and when this is not the case, the person in question does not seem to fulfill the socio-cultural ideal of travel.

The deportees are as obsessed with travel and Europe as people in Benin City. Trying to explain why she wanted to go to Europe in the first place, Daisy kept repeating "everything is beautiful there; I never liked this country [Nigeria]." Daisy's definition of "beautiful" includes many infrastructural factors. Daisy cites the constant electricity and water supply, no rubbish on the street and leveled, paved roads as the best things about Europe. Daisy and other migrants and non-migrants consider the ample supply of jobs in Europe also "beautiful." It seems that the failures and difficulties suffered in Europe do little to damage the dreamlike image of it as a kind of paradise.

When asked about how and why they came to travel, all informants talked about suffering. Rachel considered it an exhaustive explanation when she said "I travel because the suffering here is too much." Trying to specify what this suffering meant, most of the women would begin listing the things that make up suffering: no job, no money, hunger, no electricity. The most obvious interpretation of this suffering, and one that is shared by many people in Benin City, is poverty. This is also how Rachel and the other informants analyzed the causes of their migration. There were no jobs for them in Nigeria, and no possibilities for them to educate themselves. Okanga (2003: 8), a Nigerian migration scholar and migrant himself, goes as far as to say the economic situation in Nigeria amounts to "economic persecution" which drives Nigerians to seek economic survival elsewhere.

There is, however, a consensus among migration scholars that there is no inextricable link between poverty and migration. It is usually slightly betteroff people who tend to migrate, rather than the poorest of the poor (De Haas, 2007). Women's interpretations of poverty, then, can better be understood in the context of their personal situation as well as the economic circumstances in the region. To begin with, none of the informants are or have been among 
the poorest of the poor. These women are not, for example, begging and sleeping on the street. Some of the informants, such as Hope, live in comfortable houses whereas others, such as Pauline, share tiny, moldy rooms with their families. Yet others, such as Joyce and Courage, have nice mobile phones, fashionable clothes, televisions, and hi-fi sets. None of them are literally starving, even if making ends meet is a challenge.

Earning a living is not easy given that Nigeria battles high rates of unemployment (The World Bank, 2010). Many people, also many of the informants, consider setting up one's own business as the only way of finding sustainable employment. Lack of capital often stands in the way of such plans. In the informants' families, whatever assets the family may have possessed, they were considered to be better invested in migration than in business. A low-capital form of business is informal trade, which accounts for as much as $85 \%$ of the employment in the region (United Nations Development Program, 2006). Overlapping with other income-generating possibilities, young unmarried women in Nigeria engage in multiple sexual relationships that yield economic benefits (Smith, 2010). Despite a high level of economic gender inequality in Nigeria, women in Edo State are said to enjoy greater economic independence than those in other parts of the country (Van Dijk, 2001).

The quest for social mobility is, however, not merely a personal one. None of the women failed to mention that their family members were suffering, and that they traveled in order to help them. Pauline analyzed the plight of her family as follows: "Because we are many and my dad is very old. There is no money to feed us; too many children." Despite the socio-cultural ideal of travel as a women's activity, not all informants were enthusiastic about going abroad. Rachel, now 35 years old, traveled to Italy in 1995 when her parents suggested she should go: "They said I should go and help them. I said I didn't want to go." Time and time again they pressurized her; she eventually caved in.

Rachel's sacrifice illustrates another dimension to suffering. By using an idiom of suffering, women stress their willingness to sacrifice themselves for others (cf. Notermans, 1999). The emphasis on sacrifice enables women to downplay their own eagerness to travel. As travel is associated with women's migration, it is linked to sex work in many people's minds; such a link can be renounced by claiming that there really is no other option than this to help the family. A similar mechanism is at work in the case of Eastern European sex workers in Italy. Their stories revolve around the notion of obligation, and how they are forced by economic necessity to do sex work. They insist that they do this for their parents, family or children, and therefore not for themselves (Andrijasevic, 2004: 135-140). 
In summary, in this context the emic term "travel" signifies a socio-cultural idea and practice of gendered migration, often by women and for sex work. The geographical mobility of travel is intimately connected to social mobility, where the first serves to produce the second. The informants traveled because travel was supposed to result in social mobility, not in the first place raising their own standard of living, but that of their families. Considering the economic circumstances in the region around Benin City, migration may be a plausible avenue to social mobility.

\section{"Please let me stay, my people are suffering in Nigeria": The Deportation}

When Rachel heard that the police were going to deport her from Italy where she had been engaged in sex work for the past 8 years, she first thought about her family. She was 28 years old at the time. Despite the often harsh life in Europe (sexual and economic exploitation, isolation, absence of family, bad housing, the need to hide, and remain invisible), most informants reacted similarly when they were deported: they did not want to return. Regrets about not being able to stay were equally great for informants who had spent 2 weeks in European immigration detention as for those who had stayed in Europe for 8 years.

All but one of the informants were undocumented at the time they were caught and deported, and their experiences tell a story of what it means to be "deportable," to use the term of De Genova (2002) for migrants without papers in the European Union. Three of the four informants who migrated before the mass deportations from Western and Southern Europe started around 1999 had at some point possessed a residence permit, as these were easier to obtain at that time. Maria (deported in 1995), had applied for asylum in the Netherlands but was rejected. The other women had not applied for documents as they were afraid to come into contact with the authorities. Their experiences reflect the growing anxiety about the presence of undocumented migrants in European Union countries. Sitting on a hot afternoon in the shade at a makeshift bar somewhere on the outskirts of Benin City, Courage and her friend Francis, both deportees, reflected on life in Europe: "Up there we can never sit like this outside and relax, up there you always have to look out," Francis said. All stories of undocumented life in Europe revolve around having to "look out" for the police as skin color and gender put African women at risk because "everybody knows what African women go there to do!" The women who were not engaged in sex work mainly spoke about their deportability in terms of 
having to look out. The informants who were involved in sex work, four out of the 17 , faced more dangers on the street than the other women. Rachel recalls her days in Italy:

Strange people would come and beat us up on the street, sometimes they kidnap some girls. The police say you should go home. Even if you're in the house, the police will come and take you. You're not free inside and you're not free outside.

In the end, all of the informants were caught by the police, mostly in everyday situations. Hope was arrested on the street when she was out buying groceries: "When I was going out, they hold me, I have no paper with me." Not having the right papers is consistently repeated in the stories of getting caught, giving a certain rhythm to the narratives. This repetition, and the framing of deportation as something that follows not having the right papers, suggests that the informants are afraid of being blamed for being sent back early and for not having earned enough money.

The system of deportation does not always operate consistently. Beatrice, 40 years old, was on her way to a corner bar in Torino on a September morning in 2005 to get a cappuccino, and had only her keys and some small change with her. She had a residence permit which her brother had helped her to obtain, but the papers were in her apartment. The police stopped Beatrice on the street and asked for her documents. They would not believe her or go with her to the apartment to get them. Instead, she was pushed into the police car, taken to a police station and eventually deported. Every time Beatrice recounts the story, she trembles and eventually starts to cry.

Stories of undocumented life in Europe are saturated with deportability, although the women doing sex work obviously faced greater dangers than the other informants. Rachel's words, "you're not free inside and you're not free outside," seem to capture the immobility involved in being deportable. Of all the informants, 12 ended up in detention after having spent some time in Europe. Five informants were detained on arrival at a European airport. The period of detention ranged from a few weeks to a year before deportation.

Lucy, 24 years old, describes her time in detention at the Schiphol airport in Amsterdam with the following words: "I beg them, let me go inside this place, let me go to the town." The person who was escorting her, and who had organized her travel, was supposed to provide documents that would allow her into the country legally, but vanished once they got off the plane. His intention was probably to have Lucy admitted to an asylum facility where he could pick her up, and thereby avoid trouble with Customs. This strategy was popular and effective for some time in the migration and / or trafficking of Nigerian women 
into the Netherlands (Kamerman and Wittenberg, 2009). She was therefore at the airport with no papers and no money when the airport officials caught her. She says: “They told me at the airport they don't allow me to stay in their country. And I was crying, crying, crying. They take me to outside the airport and then they put me in a vehicle and carry ${ }^{3}$ me to camp."

Questions about life in "the camp," as the informants called immigration detention centers, were initially answered with a simple "nothing" by some deportee women. For example, Courage reacted to the question thus: "It was nothing; I did nothing in the camp, that's it!" Such answers suggested complete incomprehension of the inquiry; obviously the informants did not consider their detention worth talking about. Talking about deportation produced similar reactions. Part of this reluctance to talk about detention can be ascribed to the shame of being imprisoned. Another, somewhat overlapping, interpretation of "nothing" is that it is an indication of immobility, as the informants were deprived of both their physical and social mobility. "Doing nothing" can also be interpreted literally, as there is little to do in detention. Lucy, who begs the guards to let her go to Amsterdam at the beginning of this section, says she was doing nothing all day long in the camp. "They will lock you inside, you can't see outside. All those people are crying there. We sit in the room the whole day, crying whole day." Lucy and the other woman in the room with her were only allowed outside for half an hour every day. Lucy talks about her detention rapidly, gasping for breath at the end of each section, as if to underline the asphyxiating immobility of being detained and doing nothing.

But not all detention experiences were the same; Essi, for example, succeeded in negotiating the terms of her detention to some extent. She was detained for 11 months in Italy and as her detention went on, she obtained all sorts of duties: cooking, cleaning, and tidying the place up. Whereas most deportees would be deported within a few weeks, Essi said that she was supposed to be picked up by the madam who had organized her travel, but never came. Essi's persistence made it possible for her to stay longer in Italy.

The experiences of immigration detention speak of immobility. When this is juxtaposed with the expectations the informants had about being on the move, bringing about social mobility for themselves and their families, it becomes obvious that the deportees are overwhelmed by their total immobility, both in the physical and in the social sense.

3) "Carry" means "bring" in pidgin English, the colloquial form of English that most Nigerians speak. 
Deportation from European Union countries - here Netherlands, Spain, and Italy - always happens by plane. The initial mobility of the informants is reversed by force in the act of deportation. Comparison suggests that the level of force used varies, partially because the deportations happened at different times and partially because different countries settle it differently. In terms of numbers, the deportations of informants range from Maria's deportation in 1995 from the Netherlands alone on the plane with no police escort, to the mass deportations such as those experienced by Pauline who was deported together with some 100 women from Italy in 2003. In most cases, the deportees were taken hand-cuffed onto the plane, whereupon the cuffs were removed. There was little or no physical resistance from the informants or other deportees.

Pauline ended up being deported, she suspects, because her madam did not want her to start earning her own money; she notified the police as soon as Pauline had paid her 5,000 US dollar debt. Staff of NGOs that combat human trafficking often hear such stories from women involved in sex work in Europe. When a woman has repaid the debt for her travel and is about to start earning her own money, the madam notifies the police, since such a woman is less profitable to her. Pauline narrated:

The police picked me up when I was working on the street, they snap ${ }^{4}$ me, they take my ID card. I spend 2 days in cell. Then I was deported from Rome but I did not work there; I work in Torino. On the plane I was just crying, this is how I ended. I was crying, I did not come back with anything. I wanted to stay and try to earn some money. There were 100 Nigerians deported on the same plane from all places in Italy: Milan, Napoli, Rome. The other people on the plane were cursing the policeman who picked them up, saying 'Why they bring me back to Nigeria, there is nothing there'. There were 100 policemen to escort the people on the plane. The police was between the Nigerians: a Nigerian here, escort here, and a Nigerian here. I was left with this shirt and these jeans and nothing else. That was the only thing I had with me coming back. When I came back from Italy, I came with nothing - just trousers and a shirt, nothing else. But by God's grace I am still alive. When the plane landed in Lagos, they called Nigerian police from the airport and some of them in the plane were taken to the police station in Lagos. But I got off the plane and just ran away when the police came.

Pauline's forced return was one of the great mass deportations of Nigerian women from Italy in 2003. The mass deportations were perceived as especially threatening by virtue of the large number of police officers present. Living without documents in Europe had taught the informants to be afraid of the police. Such mass deportations were remembered most vividly by the informants, even if they had occurred years earlier. In addition to the threat of violence they represented, police officers were perceived by some deportees

4) "Snap" means taking a photograph in pidgin English. 
as particularly emotionless. Essi was comforted by another passenger on the plane, whereas the police escorting her deliberately ignored her plight:

I was feeling so bad, so bad, I started crying. Other people were looking at me, a white man next to me said just take it easy, it is not end of life. The policeman travelling with me was just looking, he did not even say anything, just turned his eyes away.

Whereas Pauline refers to herself and others crying, some of the other informants would only say that they were not happy being on the plane. Others, such as Jane, reacted dramatically. When Jane talks about being on the plane, she mimes holding a knife in one hand, slitting the wrist of the other, and says that she wanted to die at that moment because of the shame of going back, and because there is nothing in Nigeria, "no money, no possibilities."

In summary, both the deportations and how the deportees experienced them would vary; however a common theme was the pain of coming back with nothing. In some cases, the informants would only say that they were "not happy" to go back with nothing but in most cases the reactions were more extreme, such as Jane's talk about slitting her wrists. There was no direct association between the level of hardship endured during migration and the experience of deportation. Experiences ranged from Jane's relatively safe existence cleaning McDonald's at night to Pauline's, who went through hell getting to Europe through the Sahara and was then forced to do sex work; but both were truly devastated by coming back with nothing.

All in all, the deportation reverses the mobility of the deportees by turning it in an unwanted direction, which frustrates women's project of social mobility. Paradoxically, all deportees would have preferred to stay in Europe, despite the hardships entailed in an undocumented existence. The social mobility, wealth and the potential for supporting one's family clearly outweigh the immobility of such an existence, having to look out and not being free to move. This suggests that although geographical and social mobility are intimately connected, when set against one another, social mobility is more important.

\section{"When I was back from Italy the suffering was too much": Life after Deportation}

While the informants pointed to suffering as their main reason for migration in the first place, they described their lives after deportation with this same notion of suffering. Before traveling to Europe they were suffering and now they were suffering again. They felt that they were back to square one and that all investments had been made in vain. 
When Rachel came back to Benin City after 2 days in a cell at the Lagos airport, she first stayed with a friend. She stayed at his place and he took care of her, and also gave her money. However, she could not put off going to her parents indefinitely. Rachel describes her first meeting with her mother after coming back, as follows:

My mother was crying. By then I had just paid back my debt to the sponsor and started to earn money [at the moment of deportation]. My mother thought that we were going to start getting money. But she was happy to see me alive too. Not everybody comes back. Many others died over there. I told my mother that it is not farm work I did there. She said that's not what that woman [the madam] said and first she scolded me for making prostitution. I told her I had to make prostitution; if you don't, they come and say they beat your parents. So I told my mother I had to pay back to earn money. When I had paid back, I also wanted to send money for my mother. My mother says I should start a business but I ask her how can I start when I have no money. When I was back from Italy the suffering was too much, unbearable. I say I can't go back to the street; let me do something with my hands.

In Rachel's first year after deportation, 2002, she found a husband, got married, and had her first child. The marriage was not always stable because the husband had financial expectations that she could, or was not willing to meet. Deported women often have to deal with such economic expectations. There are many stories going around in Benin City about the riches migrant women have succeeded in gathering in Europe; anyone who has traveled is expected to have money. Rachel received a microcredit loan from an NGO running a program for deported women which she used to start a provisions store selling drinks and cigarettes. She has finished paying it back but the business is not running well. She has school fees and other expenses to pay and there is little money to keep the shop going.

Although there is a social stigma attached to being deported, Rachel was the only informant who was open about what people said about her: "They'll be laughing at me, the rich people; look at them, they go and now they get deported. They say mean things about us, that we do prostitution. They laugh at us." She analyzed other people's laughter through the prism of class. According to her, the social stigma is about rich people laughing at poor people who try to make something of themselves and fail. The fieldwork data indeed confirms that there is a class dimension to the social stigma; highly educated and well-paid people are more likely to condemn deportees and their travel. In their opinion, less wealthy and less educated people do not have any business going abroad.

During conversations on the street and in bars and restaurants, one notices a certain ambivalence regarding deportees. Some, such as shopkeeper Linda, 
express their sympathy: "There are so many deportees here, and they are all suffering so much!" This sympathy is especially common when talking about deportees without mentioning their gender. The tone changes when people explicitly or implicitly talk about women deportees, who go to Europe for no good, to "make prostitution." Even though money and sex are perceived to be intimately connected in a number of situations in Nigeria (Smith 2010), sex work is widely condemned on moral grounds. As long as the exchange between sex and money takes place in the respected context of marriage, women's sexuality remains respected. If economic transactions do not take place in the context of mutual long-term commitment between a husband and a wife where a wife gives sex and food in exchange for money and children - the economics of women's sexuality become problematized and may be considered sex work (Notermans, 1999). Recent decades have witnessed a greater permissiveness towards women's premarital sexual relations in southern Nigeria. The exchange of sex for money is becoming increasingly acceptable, as are relationships that are less stable than marriages (Smith, 2000: 2010). The difference between sex work and other sexual relations seems to lie in the absence of a social relationship in sex work. As Nigerian women travel to Europe to find a job and not primarily for marriage, people presume they will work in prostitution. The social stigma for the women deportees is therefore mainly associated with sex work.

All in all, one can say that migrant women are not stigmatized, even when they do sex work or make financial use of their sexuality within marriage, as long as their geographical mobility brings about social mobility for both themselves and their families. Decisive for the stigma of deportees is their social immobility which is connected to their gender and their role in kin networks. The stigma of coming back with nothing has been widely recorded in diverse return migration settings all across the world (Van Houte and Davids, 2009; Bastia, 2011). The Nigerian case is particular in that such stigma is so intimately intertwined with gender, kinship and morality.

There is no official structure of assistance in place for people who are deported to Nigeria, so they mostly rely on family and friends. Some EU states give a relatively small sum of money, ranging from $€_{50}$ to $€_{200}$, to help the deportees with immediate needs in the first days. A number of NGOs provide assistance to victims of trafficking both in Benin City and elsewhere in the country. They often co-operate with the Nigerian government organization NAPTIP, National Agency for the Prohibition of Traffic in Persons and Other Related Matters, but all of these agencies have limited funds. None of the informants received any assistance immediately upon arrival or in the first months. 
However, five of the 17 women found financial help later on through such organizations. Not all women who travel qualify as victims of trafficking and even those who do, such as Pauline, refer to their experiences as "travel", and not as trafficking. In addition, NGOs suspect deportees of making up stories of victimhood. This makes deportees reluctant to turn to NGOs for help.

Especially women's social networks and kin take care of deportees on their arrival. The term kin should not be interpreted merely as birth kin, since social kin can also provide considerable assistance in times of hardship. Whereas Rachel, ashamed, waited a while before meeting her family, most other deportees returned immediately to their family. Deportees mostly spoke of their mothers and aunts as the kin they would go back to, although sometimes other female kin were mentioned. Esohe, one of the informants who landed in detention immediately on arrival in Italy, was thrown out of her parents' house by her father and was still staying with her aunt two years after her deportation. All the deportees who were helped by their kin were housed by a family member. For Regina, now 32, this help still proves invaluable, 11 years after her deportation. Rachel and Hope were the only informants who married after deportation, and relocated to their husbands' household. The other informants were living with friends or family. These stories demonstrate the importance of kinship ties for the deportees.

While living with family, deportees are also aided by their kin in other living costs such as food, but they are also expected to contribute to the costs. This is perhaps not very different from other Nigerian adults living with their family. The combination of guilt and pressure to contribute above one's means is, however, typical of the situation of deportees. Jane was doing everything she could to travel again as she was feeling guilty about using up her parents' savings and coming back empty-handed. At the same time, her parents were putting pressure on her, constantly reminding her that they could not help financially since she had already spent all their savings. Similarly, Rachel's mother expects her somehow to compensate for the losses. Her mother's expectations of starting up a business without having any money, seem to be guided by the dreams of welfare she hoped Rachel would fulfill in Europe and not by the realities of everyday life. The parents of Jane and the mother of Rachel will not be satisfied by a small contribution to the household budget; they expect more from their daughters.

Despite being relieved and even happy for having their daughters back alive, almost all reunions between parents and daughters or aunts and daughters were filled with sadness and disappointment. This disappointment was internalized by all the deportees who wished above all to be able to help their family in some way. 
Whereas most women were confronted by their family for coming back with nothing, none of the men were. Among the small (4) sample of deported men, the deportation was experienced more as a personal failure and less as a failure for the family. Paul, 43 years old, was preoccupied with failing to find "greener pastures" as he put it, because many of the men he studied with had migrated and earned a lot of money. Paul had been deported some 15 years ago and was still struggling to find sustainable employment. This gender difference suggests that social immobility for the women is experienced through the kin relationships, whereas men experience their social immobility more as a personal failure. This finding contrasts with studies in other contexts where male deportees' experiences of failure are formed by relationships and experienced in relation to their kin (Drotbohm, 2011; Hagan et al., 2008). For the women deportees in this study, social mobility is social in two ways. The first dimension is the traditional understanding of the term "climbing the social ladder." The second dimension concerns women's ability to mobilize kinship relations and to keep on going with the help of the family.

All the women deportees involved in this study had found some way of generating an income since their deportation, however meager it may be. Yet none of the informants were content with their financial situation, not even the ones helped by an NGO to start a business. The deportation certainly does not mark the end of their mobility; every single informant hoped to go back to Europe one day. Which destination in Europe did not matter, as long as one would not be "stuck" in Benin City. Since this study focuses on deportee women in Benin City, there is a self-selection in the sample for those deportees who have stayed and have not gone back to Europe, mostly due to lack of funds. So far, Regina was the only informant who had tried to go back. This was in 2004 and she was going to cross the Sahara overland but backed down after news about blockages along the way.

It is impossible to estimate the number of women, and men, going back to Europe after their deportation but both deportees and NGOs dealing with trafficking expect the majority of deportees to go back. NGO representatives could recount numerous stories of deportees whom they had helped, only to discover they had gone back to Europe. Most deportees knew at least someone with whom they had been deported who had gone back. Even the women who had gone through real hardship doing sex work were eager to go back, although they would not want to do this work again. The idea of being confined to immobility, of having to look out constantly, did not diminish the enthusiasm for going back. Lack of funding, however, prevented the informants from fulfilling this dream. 


\section{Conclusion}

The case of Nigerian deported women diverges from research on return migration and deportation elsewhere in that women, in this context, are constructed as family providers. This gender aspect has a deep impact on their lives after deportation. The underlying socio-cultural idea of travel as a women's activity is not particular to the families of the informants in this study but is generally shared in Benin City. Considering the links between travel and sex work, either voluntary or not, and the repercussions of failure to achieve social mobility for women, we should be careful not to celebrate the notion of "travel" as purely emancipatory. We argue for an understanding of the complexity of Nigerian women's migration instead of placing it into a dichotomous position of either socio-economic emancipation or being victims of "the breakdown of family structures, and the lack of valid, efficient social reference models that replace traditional models" (Aghatise, 2004: 1132).

The traditional male bias of migration studies has among others been attributed to the neoclassical theory and ideas such as push-and-pull factors which seemed to disregard women's contributions to economic life (Pessar, 2003). Castellanos and Boehm (2008) implicitly place gender and economic analysis in opposition as they say that migration continues to be perceived mainly in economic and not in gendered terms. The Nigerian notion of travel and the ways in which geographic and social mobility are intimately connected suggests that economic analysis should actually be gendered, since in this context the obligation to generate social mobility is mainly an economic obligation of women.

Not only is gender significant in the way in which migration is seen in the context of the deportees' origin; it also structures the experiences of deportation and post-deportation life. Gender works here through the notion of travel, where geographic and social mobility feed into each other. Deportation reverses the mobility of deportees, which echoes the analysis of Peutz (2006) when she argues that the disruptions caused by deportation are all gendered by nature. Deportation disrupts family, reproductive, and work lives. The Nigerian women deportees, however, did not lead stable or sedentary lives which were then disrupted by deportation. It is rather their longing for social mobility that is upset by their deportation.

Studies on deportees have indicated the central role played by notions of home and belonging in post-deportation life. In addition to having their lives disrupted, deportation brings individuals to places with which they are not familiar, where they do not fit in, feel at home, or belong (Peutz, 2006; 
Yngvesson and Coutin, 2006; Zilberg, 2004). The returning Nigerian deportees, on the other hand, return home and feel that they belong to a kin network that lays serious claims on them. Yngvesson and Coutin (2006) problematize the notion of return inherent to deportation, because it draws on the assumption of a single origin, even though relocation can be a new beginning where the original self is somehow cut off. For the Nigerian women in this study, return is also problematic, not because they do not belong but precisely because they do belong. The fact that they are integrated in kinship relations in Benin City means that deportation is experienced through those relationships as the family reprehends them for their immobility. As women are supposed to help the family to move upwards and to acquire additional money, their mobility is part of what Di Leonardo (1978) has termed 'women's work of kinship.' Kinship relations are not so much naturally there - especially not when relatives are spatially segregated, as in the migrants case - but must continually be maintained by mutual care. To care for the family's welfare, women must invest time and money, travel and suffer. Investments made on one side (the family left behind) have to be compensated with investments on the other side (the women who migrated).

An anthropological understanding of deportation that would not pay sufficient attention to gender might understate the experiences of deportee women. These experiences are firmly grounded in migration as a gendered socio-cultural practice as well as in the consequences of deportation for kin relations. We would suggest, in line with Gingrich and Kroner (2006: 234), that an anthropology of deportation should be integrated with a focus on gender and kinship to do justice to the complexity of the consequences of deportation on peoples' lives.

\section{References}

Aghatise, Esohe. 2004. Trafficking for prostitution in Italy: Possible effects of government proposals for legalization of brothels. Violence Against Women 10 (10): 1126-1155.

Anderson, Bridget, Mathew Gibney and Emanuela Paoletti. 2011. Editorial introduction. Boundaries of belonging: deportation and the constitution and contestation of citizenship. Citizenship Studies 15 (5): 543-545.

Andrijasevic, Rutvica. 2009. Deported: The right to asylum at EU's external border of Italy and Libya. International Migration 48 (1): 148-174.

Bastia, Tanja. 2011. Should I stay or should I go? Return migration in times of crises. Journal of International Development 23 (4): 583-595.

Bernard, H. Russel. 2002. Research methods in anthropology. Walnut Creek, CA, Lanham, MD \& Oxford: Altamira Press. 
Black, Richard and Russel King. 2004. Editorial introduction: Migration, return and development in West-Africa. Population, Space and Place 10: 75-83.

Boehm, Deborah A. 2009. "Quien Sabe?": Deportation and temporality among transnational Mexicans. Urban Anthropology and Studies of Cultural Systems and World Economic Development 38 (2): 345-375.

Brettell, Caroline. 2003. Anthropology and migration: essays on transnationalism, ethnicity, and identity. Walnut Creek: AltaMira Press.

Carling, Jorgen. 2006. Migration, human smuggling and trafficking from Nigeria to Europe. IOM Migration Research Series. Geneva: IOM.

Castellanos, M. Bianet, and Deborah A. Boehm. 2008. Engendering Mexican migration: Articulating gender, regions, circuits. Latin American Perspectives 35 (1):5-15.

De Bruijn, Mirjam, Rijk Van Dijk, and Dick Foeken. 2001. Mobile Africa: An introduction. In Mobile Africa. Changing patterns of movement in Africa and beyond, edited by M. De Bruijn, R. Van Dijk and D. Foeken. Leiden, Boston \& Köln: Brill.

De Genova, Nicholas P. 2002. Migrant "illegality" and deportability in everyday life. Annual Review of Anthropology 31: 419-447.

De Haas, Hein. 2007. Turning the tide? Why development will not stop migration. Development and Change 38 (5): 819-841.

- 2008. International migration, national development and the role of governments: The case of Nigeria. In International migration and national development in sub-Saharan Africa: viewpoints and policy initiatives in the countries of origin, edited by T. Van Naerssen, A. Adepoju and E. Zoomers. Leiden: Brill Publishers, pp. 161-181.

Di Leonardo, M. 1987. The female world of cards and holidays: Women, families, and the work of kinship. Sings 12: 440-453.

Donato, Katharine M., Donna Gabaccia, Jennifer Holdaway, Martin F. IV Manalansan, and Patricia R. Pessar. 2006. A glass half full? Gender in migration studies. International Migration Review 40 (1): 3-26.

Drotbohm, Heike. 2009. Horizons of long-distance intimacies: reciprocity, contribution and disjuncture in Cape Verde, History of the Family 14 (2): 132-149.

- 2011. On the durability and the decomposition of citizenship: the social logics of forced return migration in Cape Verde, Citizenship Studies, 15 (3-4): 381-396.

Emerson, Robert, Rachel Fretz, and Linda Shaw 1995. Writing ethnographic fieldnotes. Chicago, London: The University of Chicago Press.

Gibney, Matthew J. 2008. Asylum and the expansion of deportation in the United Kingdom. Government and Opposition 43 (2): 146-167.

Gingrich, Andre, and Gudrun Kroner. 2006. Response to Nathalie Peutz' 'Embarking on an anthropology of removal.' Current Anthropology 47 (2): 234-235.

Hagan, Jacqueline, Karl Esbach and Nestor Rodriguez. 2008. U.S. Deportation policy, family separation, and circular migration. International Migration Review 42 (1): 64-88.

Kamerman, Sheila, and Dick Wittenberg. 2009. Operatie Koolvis; Reconstructie van uniek politieonderzoek naar internationale vrouwenhandel. NRC Handelsblad, 14.3.2009.

Khosravi, Shahram. 2009. Sweden: detention and deportation of asylum seekers. Race \& Class 50 (4):38-56.

Koser, Khalid and Richard Black. 1999. The end of the refugee cycle? In The end of the refugee cycle? Refugee repatriation and reconstruction, edited by K. Khoser and R. Black. Berghahn Books. 
Mahler, Sarah J., and Patricia R. Pessar. 2006. Gender matters: Ethnographers bring gender from the periphery toward the core of migration studies. International Migration Review 40 (1): 27-63.

Miller, Alexander. 2012. Deportation as a process of irreversible transformation. Journal of Ethnic and Migration Studies 38 (1).

Nascimbene, Bruno. 2001. Expulsion and detention of aliens in the European Union countries. Milano: Giuffrè.

Notermans, Catrien. 1999. Verhalen in veelvoud. Vrouwen in Kameroen over polygynie en christendom. Nijmegen: Uitgeverij Valkhof Pers.

Okanga, Eloka C.P. Nwolisa. 2003. Njepu Amaka-migration is rewarding. A sociocultural anthropological study of global economic migration. Frankfurt am Main etc.: Peter Lang.

Pedraza, Silvia. 1991. Women and migration: The social consequences of gender. Annual Review of Sociology 17: 303-325.

Pessar, Patricia R. 2003. Anthropology and the engendering of migration studies. In American arrivals: anthropology engages the new immigration, edited by N. Foner. New Mexico \& Oxford: School of American Research Press \& James Currey, pp. 75-98.

Peutz, Nathalie. 2006. Embarking on an Anthropology of removal. Current Anthropology 47 (2): 217-241.

Peutz, Nathalie, and Nicholas De Genova. 2010. Introduction. In The deportation regime: Sovereignty, space, and the freedom of movement, edited by N. Peutz and N. De Genova. Durham \& London: Duke University Press, pp. 33-68.

Piot, Charles. 1999. Remotely global: Village modernity in West Africa. Chicago: Chicago University Press.

Smith, Daniel Jordan. 200o. "These girls today na war-o": Premarital sexuality and modern identity in southeastern Nigeria. Africa Today 47 (3/4): 99-120.

- 2010. Promiscuous girls, good wives, and cheating husbands: Gender inequality, transitions to marriage, and infidelity in southeastern Nigeria. Anthropological Quarterly 83 (1): 123-152.

Talavera, Victor, Guillermina Gina Nuñez-Mchiri, and Josiah Heyman. 2010. Deportation in the US - Mexico Borderlands: Anticipation, experience and memory. In The deportation regime; sovereignty, space, and the freedom of movement, edited by N. De Genova and N. Peutz. Durham \& London: Duke University Press, pp. 166-195.

Tiemoko, Richmond. 2004. Migration, return and socio-economic change in West-Africa: The role of family. Population, Space and Place 10: 155-174.

The World Bank. 2010. Nigeria: Country Brief. http://web.worldbank.org/WBSITE/EXTERNAL/ COUNTRIES/AFRICAEXT/NIGERIAEXTN/o,,menuPK:3689o6 pagePK:141132 piPK:141107 th eSitePK:368896,oo.html.

United Nations Development Programme. 20o6. Niger Delta Human Development Report. Abuja, Nigeria: United Nations Development Programme.

Van Dijk, Rijk. 20o1. Voodoo on the doorstep and the trafficking in young Nigerian women for the Dutch sex industry and its moral panic. Africa 71 (4): 558-586.

Van Houte, Marieke and Tine Davids. 2008. Development and return migration: from policy panacea to migrant perspective sustainability. Third World Quarterly 29(7): 1411-1429.

Wicker, Hans-Rudolf. 2010. Deportation at the limits of "tolerance": The juridical, institutional, and social construction of "illegality" in Switzerland. In The deportation regime; sovereignty, space, and the freedom of movement, edited by N. De Genova and N. Peutz. Durham \& London: Duke University Press, pp. 224-244. 
Willen, Sarah S. 2007. Toward a critical phenomenology of "illegality": State power, criminalization, and abjectivity among undocumented migrant workers in Tel Aviv, Israel. International Migration 45 (3): 8-38.

Yngvesson, Barbara, and Susan Bibler Coutin. 2006. Backed by papers: Undoing persons, histories, and return. American Ethnologist 33 (2): 177-190.

Zilberg, Elana. 2004. Fools banished from the kingdom: Remapping geographies of gang violence between the Americas (Los Angeles and San Salvador). American Quarterly 56 (3): 759-780. 